\title{
Yönetsel Cesaretin Tarihi Kaynakları Üzerine Bir İnceleme: Eski Türk Yazıtlarında Cesaret
}

\section{An Investigation On The Historical Roots Of Managerial Courage: Courage In Old Turkic Inscriptions}

İbrahim Sani Mert, ${ }^{\mathrm{a}, *}$ Muzaffer Aydemir ${ }^{\mathrm{b}}$

aprof. Dr. Antalya Bilim Üniversitesi, Sosyal Bilimler Enstitüsü, Antalya/Türkiye. ORCID: 0000-0002-2850-1865

bDr. Öğretim Üyesi Altınbaş Üniversitesi Uygulamalı Bilimler Fakültesi, İstanbul/Türkiye. ORCID: 0000-0001-8167-3159

\section{MAKALE BİLGİSI}

\section{Makale Geçmişi:}

Başvuru tarihi: 07 Şubat 2019

Düzeltme tarihi: 01 Aralık 2019

Kabul tarihi: 06 Aralık 2019

\section{Anahtar Kelimeler:}

Cesaret

Kahramanlık

Türk Yazıtları

Bilgelik

Yiğitlik

\section{A R T I C LE INFO}

Article History:

Received 07 February 2019

Received in revised form 01 December 2019

Accepted 06 December 2019

\section{Keywords:}

Courage

Heroism

Turkic Inscriptions

Wisdom

Bravery

\section{ÖZ}

Bu çalışmada, toplumsal açıdan her alanda çok önemli bir kavram, değer olan cesarete yönelik bir inceleme yapılmıştır. Cesaret, tarihin ilk zamanlarından beri insanoğlu tarafından kabul edilen temel bir değerdir. Özellikle son 15 yıllık dönemde cesaret ve kahramanlık üzerine yapılan bilimsel araştırmaların ivme kazandığı ve cesaretin akademisyenler tarafından oldukça ilgi duyulduğu görülmektedir. Yapılan bu çalışmada cesaret, hem milli tarihsel kökleri hem de günümüz modern araştırmaları çerçevesinde incelenmiştir. Bu kapsamda, eski Türk yazıtları ve mezar taşları incelenerek cesaretin ne şekilde kullanıldığı ve bunun modern araştırmalardaki cesaret yazını ile ilişkilendirilmesi yapılmıştır.

\section{Giriş}

Milletler yaşamları boyunca sosyal, kültürel, ekonomik ve siyasi değerler yaratarak, bunları kalıcı eserlere dönüştürüp gelecek nesillere aktarmışlardır. İnsanlık tarihi boyunca, her millet kendisine özel ayırt edici, kaderini belirleyecek insani erdemler, değerler geliştirmiş ve bunlara sahip çıkmıştır (Zushe, 2018: 70). Bu birikim ve değerler onları diğer milletlerden ayıran temel özelliklerdir. Milletlerin

*Sorumlu yazar/Corresponding author

e-posta: muzaffer.aydemir@altinbas.edu.tr 
ayırt edici değerlerinden biri, cesaret uygulamaları ve bunun yönetsel boyuttaki anlamlarıdır.

Cesaretin insan yaşamı için sahip olduğu önemin farkındalığı ve dolayısı ile cesaret konusunun kapsamlı bir şekilde incelenmesi, tarihin bilinen yazılı ilk zamanlarına ve özellikle Platon ve Aristo'ya kadar uzanmakta(Snyder, Lopez ve Pedrotti, 2010; Hobbs, 2000), hatta ondan da öncesinde Konfiçyus'a(Jiang, 2012) dayanmakta olup, cesaret filozoflar tarafından anlaşılmaya ve tanımlanmaya çalışılmıştır. Günümüze kadar cesaret konusunda yapılan çalışmalara bakıldığında Platon, Aristo ve Konfüçyüs'dan fazla ileri gidilemediği, cesaretin anlaşılmasına yönelik kayda değer bir bilgi üretimi yapılamadığı görülmektedir. Ancak, özellikle son 15 yıllık dönem içerisinde, başta pozitif psikoloji olmak üzere, farklı disiplinler tarafindan, cesaret konusu adeta yeniden keşfedilmiş ve günümüzün modern araştırma yöntemlerinin kullanıldığı çalışmalarla, cesaret artan bir önemle araştırılmıştır. Ancak bu önem ve artış yabancı yazında vuku bulmuş, ulusal yazında ise, nispeten çok az olan bazı çalışmalar (Örn.,Mert, 2007; Aydemir ve Mert, 2018) haricinde cesaret konusu hak ettiği ilgiyi görmemiştir.

Cesaret, yönetim yazınında, özellikle son yıllarda çalışılmaya başlanan bir konudur. Ancak, henüz cesaret ve cesaretin yönetim ve liderlik sürecindeki tarihsel kökü ve kaynakları ile başarılı uygulamaları yeterince araştırılmamıştır.

Farklı boyutlarda ve özellikle yönetsel boyutta incelenen cesaretin, Türk işletme tarihi incelendiğinde, başarıyla uygulandığı örgütsel yapılara verilebilecek en güzel örnek ahiliktir. Fütüvvetten aldığ oluşan ahilik teşkilatı, cesareti temel alan bir yaklaşım ile geniş bir coğrafyada yüzyıllar boyunca başarıyla uygulamıştır (Aydemir ve Mert, 2018: 542). Ahilik öncesinde yer alan binlerce yıllık Türk tarihindeki cesaretin köken ve uygulamaları ve bunları içeren kaynaklar incelenmeye muhtaçtır.

Cesaret konusunun hak ettiği ilgiyi bulamaması sadece tarihsel anlamdaki değer odaklı çalışmalara özgü değildir. Örneğin, cesaret özellikle pozitif psikoloji alanında ele alınmaya başlanmıştır. Pozitif psikoloji çalışmalarında, endişe ve korku en çok çalışılan iki duygudur. Ancak, endişe ve korku ile çok yakından ilişkili olmasına rağmen, cesaret, onlar kadar çalışmalara konu olmamıştır (Lopez, 2007).Bununla birlikte, cesaret üzerine yapılan araştırmalarda, cesaretin önemli ölçüde endişe ve korku ile belirlendiği vurgusu yapılmaktadır. Ayrıca, söz konusu çalışmalarda endişe ve korkunun bir ardılı olduğu belirtilen cesaretin daha kapsamlı bir şekilde incelenmesine duyulan ihtiyaç vurgulamaktadır. Nitekim cesaretin tanımlanmasında, korkuyla yüzleşmedeki sebata vurgu yapılmakta (Rachman, 1984) ve cesaret, psikolojik sağlamlığın kaybedilmesine yönelik korkuyla yüzleşme durumu (Putman 1997) olarak da ifade edilmektedir.

Cesaret dünya edebiyatında da en çok işlenen konuların başında gelmektedir. "İnsanlar, gizemin güçle birleştiği yerde büyük bir hayranlık içinde olurlar. Cesaretin doğasında, güç ve gizem birbirleri ile kaynaşmıştır. Bu kaynaşma, cesarete ayrı bir çekicilik ve sahiplenme özentisi kazandırmaktır." (Mert, 2007: 13). Bunun doğal bir sonucu olarak da cesaret bir liderin sahip olması gereken en önemli özellik olarak belirmiștir. Nitekim bu çalışma kapsamında incelenen Türk yazıtları, mezar taşları ve belgelerde, cesaretin ifade edilmesinde bilgelikten kaynaklanan güce yönelik somut ifadeler tespit edilmiştir.

Cesaret kavramının araştırılmasındaki yaklaşımlara genel olarak baktığımızda, cesaretin ahlaki bir değer olduğu vurgusu ön plana çıkmaktadır. Ahlaki cesaret, örgüt araştırmacıları tarafından üzerinde ilgi duyulan bir konu olmaya başlamıştır (Simola, 2015a; Sekerka, Bagozzi ve Charnigo, 2009; May, Luth ve Schwoerer, 2014; Harbour ve Kisfalvi, 2014). Ahlaklı davranış sadece iş yaşamında değil, yaşamın her yer ve aşamasında, insan ilişkilerinin ve dolayısıyla bu ilişkilerle şekillenecek işbirliğinin kalitesini belirleyen insan davranışıdır. Ahlaklı davranış, diğer bir ifade ile ahlaklı davranmak, bir sonuçtur. Ahlaki davranabilmek için ahlaki cesarete ihtiyaç vardır. İyi niyet veya ahlaki niyet, ahlaki davranışa hemen dönüşmez, iyi niyetin ahlaki bir davranışa dönüşebilmesi için bireyin cesaret sahibi olması gerekir (Comer ve Sekerka, 2018). Ahlaki cesaret, doğru olan davranışın, toplumda kabullenilmeme, toplum tarafindan reddedilme durumunda bile gösterilmesini gerektirir (Lopez vd., 2010: 23). Ahlaki cesaret, bir kişiye sosyal ve ekonomik sonuçlarından korkmasına rağmen, doğru olanı yaptırır (Petersen ve Seligman, 2004: 216). Cesaret bu kapsamda değerlendirildiğinde, toplumsal düzenin adaletli ve sağlıklı işleyebilmesinde ihtiyacımız olan temel değerdir.

Çalışmamızda cevabı aranan soru, Türk tarihinin önemli belgelerinde cesaret kavramının hangi özellikler taşıdığının, yönetici, liderler ile yönetim ekibinde bulunanların cesaretindeki bileşenlerinin nelerden oluştuğunun tespit edilmesidir.

Son yıllarda özellikle yabancı yazında cesaret konusunun giderek artan bir önemle ele alındığı ancak yerli yazında bu konuda ciddi bir boşluk olduğu görülmektedir. Yapılan bu çalışma ile gerek bahse konu bu boşluğu kapatmaya yönelik bir katkı sağlamak, gerekse şimdiye kadar ele alınmamış olan, cesaretin milli tarihsel kaynakları üzerine bir inceleme yapılması ve cesaret konusunda modern yazındaki tespitlere yer verilmesi amaçlanmıştır. Dolayısıyla, yapılan bu çalışmada cesaret, hem milli tarihsel kökleri hem de günümüz modern araştırmaları çerçevesinde incelenmiştir. Bu kapsamda çalışmamız birkaç bakımdan önemli olduğu düşünülmektedir.

İlk olarak, cesaretin tarihi kaynaklarına yapacağı keşfedici katkıdır. Cesaretin yönetsel boyutu konusunda yapılan çalışmaların kaynağına baktığımızda, günümüz batı medeniyetinin kaynaklarını oluşturan antik Grek kültürünün baskın olduğu görülmektedir. Güncel yazında, cesaretin diğer tarihi kaynakları hakkında yapılan çalışma sayısı neredeyse yok denecek kadar azdır. Tarihi Türk kaynaklarında cesaretin anlamlarının ortaya konması hem Türk tarihine hem de yönetim bilimi yazınına katkı sağlayacaktır.

İkinci olarak, Türk tarihi çalışmalarına yapacağı katkıdır. Tarihi Türk metinleri genellikle tarih, dil bilimi, antropoloji bilim insanları tarafindan incelenmektedir. Bahse konu belgeler, yönetim bilimi insanları tarafindan yapılan çalışmalarda, hak ettiği değeri yeterince alamamıştır. Binlerce yıldır tarihsel süreçte varlığını başarılı bir şekilde sürdüren bir milletin yöneticilerinin, 
liderlerinin yönetsel vasıflarından olan cesaretin bileşenlerini ortaya konması, yapılan çalışmalara yeni bir boyut katabilecektir. Son olarak, yapılan bu çalışmanın bundan sonra yapılacak çalışmalara yeni bir yön getirebilecek olmasıdır. Bu kapsamda, yönetim bilimi insanlarına yeni çalışma alanları ve kaynaklar sunmak, diğer bilim insanlarının çalışmalarına yeni boyutlar katarak farklı, çoklu disiplinel çalışmalara örnek oluşturabilecektir.

Yapılan bu çalışmada, öncelikle cesaret ve onunla ilişkili ve iç içe geçmiş bir kavram olarak kahramanlık konusu ile ilgili bir yazın incelemesi yapılarak, bu konuda son yıllarda ivme kazanan araştırmalardaki cesaret ve kahramanlık tanım ve yaklaşımlarına yer verilmiştir. Müteakiben, eski Türk yazıtları, mezar taşları ve belgeler hakkında kısa bir bilgi verilerek bunlardaki cesaret, kahramanlık ve benzeri ifadelerin olduğu metinler cesaret yazınındaki tespitlerle ilişkilendirilerek incelenmiştir.

\section{Alanyazın Taraması}

Çalışmamızın bu bölümünde yönetsel cesaret kavramına ilişkin alan yazınındaki yaklaşımlara yer verilmektedir.

\subsection{Cesaret Kavramı}

Günümüzde yönetsel anlamda cesaret kavramının tanımlanmasına ilişkin çalışmaların hız kazanmasına rağmen ortak bir tanıma ulaşılmamıştır. Cesaret, ilk zamanlardan beri farklı bakış açılarından ele alınan bir kavram olup, henüz kabul edilen ortak bir tanıma sahip değildir (Cavanagh ve Moberg, 1999). Mevcut yazında cesaretin tanımlanmasında referans alınan kaynaklar çoğunlukla antik Grek kültürüne dayanmaktadır. Tarihteki ilk cesaret tanımlaması kapsamlı olarak Platon'un Lakhes Diyalogu'ndaki Sokrates tarafindan yapılan tanımlamadır. Cesaret, Sokrates'in tanımlamasında bir değer/erdem olarak ele alınmıştır. Sokrates, cesareti nispeten geniş ve genel bir yaklaşımla, bahse konu diyalogunda, cesareti akıl ve metanet arasındaki denge olarak tanımlamıștır (Platon, 2001).

Cesaret toplumsal bir boyut kazanabilirse de, başlangıç olarak bireysel bir çıkışa sahiptir. Bireyin cesaretini, hissettiği korkuyu kontrol edebilme gücü tetikler. Varoluşa olan sayg1, bireyin şahsı kadar, diğer insanların varlığına karş1 olan saygısını da ifade eder (Mert, 2010: 70). Varoluşun temelinden gelen bu güç, ilk sınanmayı hissedilen bu korkuyu kontrol altına almakta verir. Bu anlamda cesaret, bireyin kendi varoluşuna olan saygıyı, diyeti ifade eden bir değerdir.

Büyük engellerle karşılaşılmasına rağmen, iyi bir sonuca ulaşabilmek için gerekli olana katlanabilme, dayanabilme kabiliyetini ifade eden cesaret (Cavanagh ve Moberg, 1999: 2), en zor seçimlerle yüzleşme istekliliği ve bunlara ilişkin korkuyla baş edebilme (Clancy 2003:132) yeteneğidir.

Cesaret, bir kişinin imkân ve kaynaklarını aşan bir durumda, algıladığı tehditle ilişkili korkusuna rağmen anlamlı, faydalı bir şekilde hareket edebilme yeteneğidir (Woodard, 2004: 174).

Cesaretin doğasının anlaşılabilmesi ve dolayısıyla da doğru tanımlanabilmesi gayreti, araştırmacıları cesaretin bileşenlerini tespit etmeye yönlendirmiştir. Direk bir tanım verme yerine cesaretin, diğer bir ifade ile cesur davranışın, yapısını oluşturan bileşenleri doğru saptayabilmek, cesaretin tanımlayabilmesini ve anlaşılabilmesini de kolaylaştırabilecektir.

\subsection{Cesaretin Bileşenleri}

Cesaretin doğru bir şekilde anlaşılabilmesinde, özellikle yapılan son araştırmalarda, cesaretin bileşenleri diye ifade edeceğimiz bazı özelliklere odaklanıldığı dikkat çekmektedir. $\mathrm{Bu}$ kapsamda cesaretin bileşenlerini vurgulayan bazı araştırmaların tespitlerine özetle aşağıda, Tablo 1'de yer verilmiştir.

Tablo 1.Cesaretin Bileşenleri

\begin{tabular}{|c|c|c|}
\hline ARAŞTIRMACI & $\begin{array}{l}\text { TEMEL } \\
\text { YAKLAŞIM }\end{array}$ & CESARET BİLEŞENLERİ \\
\hline Walton (1986: 3) & $\begin{array}{l}\text { Cesur davranış } \\
\text { özellikleri }\end{array}$ & $\begin{array}{ll}\text { - } & \text { Kasıtlı ve bilinçli düşünerek yapılma, } \\
\text { - } & \text { Zor, tehlike ve acı içeren bir durumun varlığ } 1, \\
\text { - } & \text { Ahlaki bir niyetin olması, } \\
\text { - } & \text { Kişisel risk, cefa, çile içermesi. }\end{array}$ \\
\hline $\begin{array}{l}\text { Evans ve White } \\
(1981: 420)\end{array}$ & $\begin{array}{l}\text { Cesaretin ampirik } \\
\text { tanımındaki } \\
\text { boyutlar }\end{array}$ & $\begin{array}{l}\text { - Cesur davranışı gözlemleyen, atfeden kişinin korku seviyesi, } \\
\text { - } \quad \text { Cesur davranışı yapan, atfedilen kişinin korku seviyesi, } \\
\text { - } \quad \text { Ortamın öne çıkan, dikkat çeken özellikleri, risk içermesi durumu. }\end{array}$ \\
\hline Gould (2005) & Cesaretin boyutları & $\begin{array}{ll}\text { - } & \text { Korku, } \\
\text { - } & \text { Uygun davranış, } \\
\text { - } & \text { Yüksek bir amaç. }\end{array}$ \\
\hline $\begin{array}{l}\text { Klein ve Napier } \\
(2003)\end{array}$ & Cesaretin faktörleri & $\begin{array}{l}\text { - } \quad \text { Samimiyet; doğruyu söyleme ve işitmedeki açık sözlülük, } \\
\text { - } \quad \text { Amaç; soylu ve gözü pek hedefler, } \\
\text { - } \quad \text { Cefa; disiplini içerme, alıkoyan bağlayıcı, } \\
\text { - } \quad \text { Risk; güçlendirmek, güven, ilişkiye yatırım, }\end{array}$ \\
\hline
\end{tabular}


- İstek; ilham, maneviyat, iyimserlik, umut.

- Kişinin özgür seçim ve davranışı,

- Çalışanın, bireyin önemli bir riski görmesi, tecrübe etmesi,

Kilmanın, O'Hara ve Cesur davranışın Strauss (2005) örgütsel özellikleri
- Bireyin riski kabul edilebilir șekilde mantıklı değerlendirmesi,

- Bireyin faziletli veya değerli bir amacı izlemeye yönelik tasarlanmıs davranışlar, eylemler göstermesi,

- Kişinin tehlikeye, korkuya rağmen bilinçli davranışlarına devam etmesi.
Cesaret, doğruyu, gerekeni yapmada, tehlike ile beliren korkuyla yüzleşme kabiliyetidir. Cesaret, bireyin doğru olanı korkmadan veya korkuyu kontrol altına alarak yapabilmesidir. Cesaretin kaynağını, birey için doğruların, yapılası gerekenin kaynağı oluşturur (Mert, 2018: 14). Bu yönüyle cesaretin, gerek bireysel gerek ise toplumsal anlamda devamlı geliştirilmesi ve yerleştirilmesine ihtiyaç olduğu ortadadır. Cesaretin geliştirilmesi ve sürekli hale getirilmesi için devamlı cesur davranış konusunda farkındalık yaratılması ve cesur davranma yönünde gayret sarf edilmesi gerekir. Bu anlamda cesaret yönetsel sistemin bir parçası haline getirilmelidir (Mert, 2018: 18).Bunun nasıl yapılabileceğinin ve bunu yapabilmede ne derece

Tablo 2. Kahramanlığın Bileşenleri başarılı olunabildiğinin göstergesi ve incelemesi tarihsel kaynaklardan tespit edilebilecektir.

\subsection{Cesaret ve Kahramanlik}

Yapılan çalışmalarda cesaret ile ilişkili bir diğer kavram da kahramanlıktır. Cesaret ve kahramanlık birbirleri ile iç içe geçmiş kavramlardır. Kahramanca davranış, aynı zamanda cesur davranıştır. Kahramanlar, cesur davranış gösteren ve cesur davranışlarıyla toplumun beğenisini ve sahiplenmesini kazanan kimselerdir. Mevcut yazında kahramanlık kavramının alt bileşenleri Tablo 2'de sunulmuştur.

\section{ARAŞTIRMACI TEMEL YAKLAŞIM KAHRAMANLIĞIN BİLEŞENLERİ}

\begin{tabular}{|c|c|c|}
\hline Kohen (2014) & Kahramanın Vasıfları & $\begin{array}{l}\text { - } \quad \text { Büyük zorluklarla baş edebilen, } \\
\text { - } \quad \text { Ciddi riskler alan, } \\
\text { - } \quad \text { Ahlaklılıkla yüzleşebilen, } \\
\text { - } \quad \text { Kişisel prensipler altında hareket edebilen. }\end{array}$ \\
\hline Franco vd. (2011) & Kahramanlık kriterleri & $\begin{array}{ll}\text { - } & \text { Kahramanca davranışın istekle yapılması, } \\
\text { - } & \text { Fiziksel ve sosyal potansiyel bir zarardan dolayı risk, } \\
\text { - } & \text { Eylemin sonucunun kabul edilme istekliliği, } \\
\text { - } & \text { Başkalarının faydasına hareket etme, } \\
\text { - } & \text { Kişisel bir kazanç beklentisi olmadan hareket etme. }\end{array}$ \\
\hline Sullivan ve Venter (2010) & $\begin{array}{l}\text { Kahramanlık tanımı } \\
\text { bileşenleri }\end{array}$ & $\begin{array}{ll}\text { - } & \text { Eylemin değerli ve soylu olması, } \\
\text { - } & \text { Bir rol model olarak algılanması, } \\
\text { - } & \text { İdeal bir kişisel imaj temsili. } \\
\end{array}$ \\
\hline Zimbardo (2007) & $\begin{array}{l}\text { Kahramanlığın alt } \\
\text { kategorileri }\end{array}$ & $\begin{array}{ll}\text { - } & \text { Askeri kahramanlar, } \\
\text { - } & \text { Sivil kahramanlar, } \\
\text { - } & \text { Dini figürler, } \\
\text { - } & \text { Politik dini figürler, } \\
\text { - } & \text { Politik veya askeri liderler, } \\
\text { - } & \text { Kâşifler, maceracilar, } \\
\text { - } & \text { Bilimsel icat yapan kahramanlar, } \\
\text { - } & \text { Merhamet ve şefkat gösterenler, } \\
\text { - } & \text { Mazlum, güçsüz durumda olan kişiler, } \\
\text { - } & \text { Bürokrasi kahramanları, } \\
\text { - İfşacılar. }\end{array}$ \\
\hline
\end{tabular}

Tablo 2'de görüldüğü gibi, kahramanlığın alt bileşenlerini en kapsamlı şekilde inceleme Zimbardo (2007) tarafindan yapılmıștır. Konunun tam olarak anlașılabilmesi için 12 alt başlığın detaylı şekilde incelenmesine ihtiyaç duyulmaktadır. Zimbardo (2007),kahramanlı̆̆ı 12 ayrı kategoride incelediği çalışmasında, kategorilerden ilk ikisini askeri, diğerlerini ise sivil kahramanlık olarak gruplandırmıştır.Araştırmacının, her bir kategori için nasıl bir yaklaşım, tanımlama ve örneklendirme yaptığı ve bu kahramanların neyi riske ettikleri ve/veya nasıl bir adanma, cömertlik içinde oldukları aşağıda açıklanmıştır.

Birinci ve ikinci kategorideki kahramanların vasıfları askeri niteliklerdir. Birinci kategoride askeri kahramanlar ve ciddi fiziksel risk durumlarına yönelik kahramanlar vardır. Yüksek derecede riskli ortamlara maruz kalan, bu durumda kahramanca davranan, gösterdikleri, yaptıkları davranış açısından, görevin gerekliliklerinden daha ileri giden, görevin ötesine geçen davranışları içerir. İkinci 
kategoride sivil kahramanlar yer alır. Bunlar kendi işi veya görevi olmasa da, yüksek derecede bir risk alarak cesur davranış sergileyenlerdir(Zimbardo, 2007: 468-471).

İlk ikisi haricindeki kategoriler sivil nitelikteki özelliklerdir. Üçüncü kategori dini figürleri içerir. Bütün hayatını dini hizmete adayan, dinin yayılması ve sürdürülmesi için kendini adarcasına çalışan kişilerdir. Bunlar genellikle öğretmen, eğitici olarak dini hizmetlerde bulunur ve dinin açıdan toplumda bir örnek olarak belirirler. Bu kişiler kendilerini çileli bir şekilde yaptıkları işe kurban edercesine adarlar. Dördüncü kategori, politik dini figürleri içermektedir. Bunlar, daha sonra köklü değişimleri etkilemek ve yapmak için politik alana giren dini liderleri veya derin bir dini inanç sistemine sahip olan ve bununla politik değişiklikler, uygulamalar yapan politikacılardan oluşur. Beşinci kategori şehitleri, mağdurları, kurbanları vb. içerir. Bunlar dini veya politik figürler olup yaşamlarını bir amaca hizmet etmek için tehlikeye atarlar. Altıncı kategori politik veya askeri liderlerdir. Bunlar zor bir zamanda bir milleti veya grubu yöneten, onlara liderlik eden kişilerdir. Bir milleti birleştirmek için hizmet ederler, paylaşılan bir vizyon ortaya koyar ve yayarlar, milletin veya grubun hayatını idame ettirebilmesi için ihtiyaç olan gereklilikleri somutlaştırırlar. Yedinci kategoriyi kâşifler, maceracılar oluşturur. Bunlar bilinmeyen coğrafyaları, bölgeleri keşfeden veya yeni, denenmemiş, ispatlanmamış ulaşım metotlarını uygulayanlardır. Sekizinci kategori bilimsel icat yapan kahramanlardır. Bunlar, bilimin bilinmeyen alanlarına girip araştırma yaparlar, yaratıcı ve yenilikçi yöntemleri, ispatlanmamış araştırma yöntemlerini kullanırlar.İnsanlık için faydalı olan yeni bilimsel bilgiyi keşfederler, icat ederler. Dokuzuncu kategoride merhamet ve şefkat gösterenler vardır. Bu kişiler başkalarına ciddi bir özveri gerektiren durumda yardım edenlerdir. İçinde bulunulan durum her zaman fiziksel bir risk durumu içermeyebilir.Başkalarına ihtiyaç duyan kişilere yardım ederler. Onuncu kategori mazlum, güçsüz durumda olan kişileri içerir. Bunlar düşmanca, zor koşullar altında başarılı olan, zor şartlara rağmen başarılı olup, başkalarına model olan kişilerdir. On birinci kategori bürokrasinin kahramanlarıdır. Bunlar büyük organizasyonlarda çalışan, karşılaştıkları büyük büyük baskılara ve anlaşmazlıklara rağmen değerlerini, prensiplerini ayakta tutabilen kişilerdir. On ikinci kategori ifşacılardır. Bunlar bir organizasyonda, yasadışı veya etik olmayan durumları, eylemleri herhangi bir mükâfat veya çıkar beklentisi olmadan, rapor eden, bildirenlerdir (Zimbardo, 2007: 468471).

Tablo 2'de yer alan yaklaşımların dışında cesaret bağlamında kahramanlığın özelliklerine ilişkin başka çalışmalar da mevcuttur. Alison ve Goethals (2011) kahramanlığın, kahraman davranışın tanımlanmasının güç olduğunu vurgulayarak, bu güçlüğün, kavramın kültürel, tarihsel ve insanların kahraman davranışa yönelik algısını şekillendiren durumsal faktörlerin doğasına bağlamıştır.

Cesaretin öncüllerinin tespitine yönelik yaptıkları çalışmada Howard ve Cogswell (2018: 11) metanetin, proaktif kişiliğin, güç mesafesinin, güçlendirici liderliğin, yaşın, algılanan riskin cesaret davranışı üzerinde etkili olduğunu tespit etmiştir. Bu araştırmada ayrıca, proaktif kişiliğin cesaret davranışı üzerindeki etkisinde algılanan cesaret faydasının düzenleyici bir etkiye sahip olduğu da belirtilmiştir. $\mathrm{Bu}$ ve benzeri çalışmalarda cesaretin öncülleri tespit edilmeye çalışılmış olsa da, daha kapsamlı bir yaklaşımla cesaretin kökenlerinin ne olduğunun anlaşılması ayrı bir öneme sahiptir. Bu kapsamda yapılan bu çalışmanın bundan sonraki bölümünde nispeten cesaretin milli köklerine diğer bir ifade ile kullanımına yönelik tespitleri yapabileceğimiz eski Türk yazıtları, mezar taşları ve belgeler ile burada araştırma konumuz kapsamında geçen ifadelere yer verilecektir.

\section{Eski Türk Yazıtları, Mezar Taşları ve Belgeler}

Milletler yaşamları boyunca pek çok birikime sahip olurlar. Maddi ve manevi unsurlardan oluşan bu birikimler zaman sürecinden geçerek günümüze ulaşırlar. Milletlerin maddi miraslarından birisi de yazılı kaynaklardır. Türk tarihinin maddi kaynaklarından birisi, farklı zaman süreçlerinde farklı coğrafyalarda meydana getirilen yazıtlardır. Eski Türk runik metinler, Türklerin ilk yazılı belgeleri olması münasebetiyle önemli bir yere sahiptir (Y1lmaz, 2018: 261). Yazitlar, özellikle Orta Asya coğrafyasında olanlar, kadim Türk tarihi hakkında detaylı bilgiler içermektedir. Özellikle, İslamiyet öncesi çok az belgeye sahip olan Türk tarihinin (Gömeç, 2000: 64) en önemli kaynaklarından birisi de yazıtlardır. H. Namık Okun'a göre "Eski Türk Yazıtları” M. Ergin'e göre "Orhun Abideleri” ve V.Thomsen'e göre de "Orhun Yazıtları" adı ile ifade edilen taş üzerine yazmalar Güney Sibirya'da Yenisey Irmağı'nın yukarı mecrasına yakın yerlerde bulunmaktadır (Bademci, 2014: 30). Türk tarihinin ilk eserlerinden olan bu kitabeler, Göktürkler'in siyasi merkezi olan, Ötüken'in yanında ve Orhun nehrinin yatağında hazırlanmışlardır (Öztürk, 1996: 16).

Göktürk Yazıtları Orta Asya'da yaşayan Türk Milleti unsurlarının yaşantısı, tarihine ait pek çok kapsamlı bilgiyi içermektedir. Öyle ki, bu kutsal taşlar üzerine nakşedilen acı-tatlı yaşam tecrübeleri, her asırda yeniden şekillenmiş ve nesilden nesile, gerek dil gerek edebî eserler vasitasıyla aktarılarak günümüze kadar gelmeyi başarmıştır (Şenocak, 2001: 166). Göktürkler, milattan önceki asırlarda, Hunlar tarafindan kurulup, değişen sülaleler ve boylar idaresinde süregelen Asya'daki büyük Türk imparatorluğunun 6 . asırla 8. asır arasındaki devresinde hüküm sürmüşlerdir (Ergin, 1989: 7). Enginün'e (2010) göre; Göktürk yazıtlarından evrensel gerçekler, atasözleri ve deyimler yanında davranış unsurları da bulunmaktadır. Ayrıca, Yenisey yazıtları bölgesinde Ugbat nehri civarında mezar taşlarından oluşan mezarlık (Orkun, 1940: 416) bir dikili taş grubu önemli veriler içermektedir.

\section{Tarihi Türk Kaynakları ve Çalışma Uzayı}

Çalışmamızda Orta Asya'daki yazıt, mezar taşları, çeşitli belgeler/yazmalar incelenmiştir. Orhun, Yenisey Yazıtları dönemin koşullarını anlatması bakımından son derece önemlidir. Bu kapsamda, bu bölgede yer alan yazıtlar, mezar taşları çalışmamızda ilk incelenen metinlerdir. Bunların dışında yine farklı araştırmacılar tarafından 
bulunmuş, farklı dillerde yazılmış Türk tarihi ve yöneticilerine ait çeşitli yazma, yazılı eserler de incelenmiştir. Çalışmamızda, doğrudan cesaret, kahramanlık ve bunlarla eş anlamlı kelimeleri ifadelerin yer aldığı yazıt ve metinler incelenmiştir. Doğrudan bu ifadelerin yer almadığı ancak yöneticilerin benzeri özelliklerini içeren eden ifadeler incelenmemiştir.

Çalışmada kullanılan yazıt ve belgeler; Orhun Abideleri, İheHüşotu Yazıtı, Üçüncü Uygur Yazıtı, Ulug-kem Yazıtı, Uybat Yazıtları, Tunyukuk Yazıtıdır. Orhun abideleri Göktürk devrinden kalma kitabelerdir (Ergin, 1989: 7). Bu kitabelerin yanında Küliçur adlı bir Türk beyinin adına dikilen İheHüşotu Yazıtı Orta Moğolistan'da İheHüşotu denilen yerde Kotwicz tarafindan bulunmuştur (Orkun, 1994: 135). Diğer yandan, Çince metinden çevrilen dokuz oymaklı Uygurların fevkalbeşer zeki ve harikulade savaşçı olan Alp Bilge Kağan'ın yazıtı ve onun yazısı Alp inancı Bağa Tarhan tarafından yazılmıştır (Orkun, 1938: 232). Yenisey nehri havalisinde bulunduğu için umumiyetle bu adla tanınan yazıtların tarihi Orhun yazıtlarından daha eski olan Ulug-kem mezar taşı, Barlık Yazıtları, Uybatmezar taşları da (Orkun, 1940: 415-553) çalışmamızda kullanılmıştır. Yazıtların dışında, kâğıtlar üzerine yazılmış olan metinler de incelenmiştir. Tun - huang civarındaki mabetlerde Göktürk yazılarıyla yazılmış olan el yazması şimdiye kadar elde edilen yazmaların en dikkate şayan olanidır (Orkun, 1938: 263).

\section{Eski Türk Yazıtları, Mezar Taşları ve Belgelerinde Geçen Cesaret, Kahramanlık Bileşenleri}

Eski Türk yazıtları, mezar taşları ve yazılı kaynakları incelendiğinde, metinlerin sıradan olay ve kişileri ifade etmediği, toplumda öne çıkan, beğenilen, sayg1 gören, imrenilen kişi ve niteliklerin vurgulandığ 1 görülmektedir. $\mathrm{Bu}$ niteliklerin şekillenmesinde, savaş ortamları diğer bir ifade ile tehlikeli ve özveri gerektiren zor şartların varlığı, bir ölüm kalım meselesi, varlığın sürdürülmesine dayandığı anlaşılmaktadır. $\mathrm{Bu}$ durumlarda, bireylerin başarısı sahip oldukları cesaretle ilişkilidir. Bireyin cesaret seviyesi bir tehlike karşısında, bir tehlikenin algılanması durumunda nasıl davranacağı üzerinde direkt etkilidir (Rachman, 1984). Eski Türk belgelerinin yaşandığ dönemlerin siyasi, askeri ve yönetsel koşulları cesarete dayalı bir yönetim uygulamalarını zorunlu kılmaktadır.

Cesaret, bireyin kendi veya başkalarına yönelik algıladığ iyiliği elde etme veya kaybetmemek için muhtemelen korku içeren tehlikeli bir durumda, uygun risklerin hesaplandığı, istekli, gönüllü bir davranıştır (Shelp, 1984: 354). Eski Türk yazıtları, mezar taşları ve belgelerde yer alan ifadeler bu tanımların ötesinde anlamlar içermektedir.

Türk yazıtlarını incelediğimizde, belgelerde cesaret ve kahramanlığı tanımlayan ve bu kavramları tamamlayan ifadelerin yer aldığı görülmektedir. Belgelerde cesaret iki yönetici kesimi tarafından nitelenmektedir. Birincisi, yönetici konumunda olan hakan vb., diğeri de yüksek unvan ve pozisyona sahip komutanlar, danışma, yardımcılar yani üst yönetici konumunda olan hakanın mahiyetidir. Kahramanlık özelliği de ağırlıklı olarak askeri bir nitelik olarak ele alınmaktadır. Metinlerde kahramanlık yönetici konumundaki liderler için kullanılan bir niteliktir. Metinlerin geçtiği coğrafyadaki ortamın özellikleri düşünüldüğünde, askeri özelliklerin daha fazla öne çıktığı görülmektedir. Tablo 3'de çalışmada kullanılan metinlerde cesaret ve kahramanlığı niteleyen kelimeler yer almaktadır.

Tablo 3. Cesaret ve Kahramanlık Tanımlayıcıları

\begin{tabular}{lll}
\hline \multirow{2}{*}{ CESARET } & YÖNETİĊ & Yüksek deha, maharetli, bilici olmak, bilgili insan, akıllı, yiğit/alp. \\
\cline { 2 - 3 } KAHRAMANLIK & MÄYET & Bilge/akıllı. \\
\hline
\end{tabular}

İncelediğimiz metinlerde iki ayrı kavramın yöneticilerin ve maiyetlerinin cesaret ve kahramanlı bileşenlerine baktığımızda öne çıkan, ortak olan ve birbirini bütünleyen özelliklerin olduğu görülmektedir. Şekil 1'de her üç gruba ait cesaretin yönetsel özelliklerinin ortak ve ayırıcı noktaları yer almaktadır. 


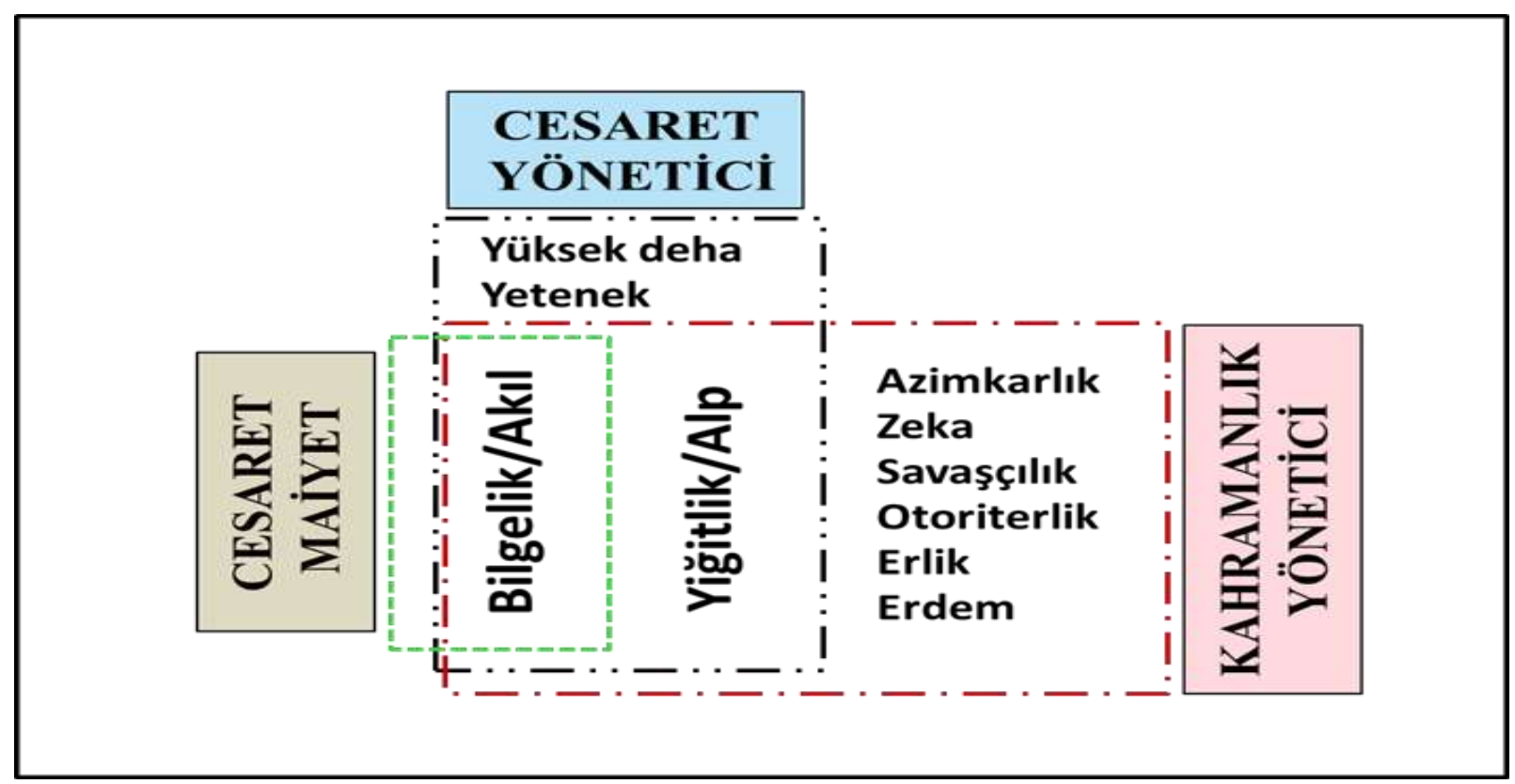

Şekil 1. Cesaret ve Kahramanlığın Bileşenleri

Mevcut yazında genel olarak cesaretin kaynakları korku ve endişe olarak belirtilmektedir (Lopez, 2007). Ancak, ilgili yazında cesaret ve kahramanlık davranışlarının kaynakları farklı zaman dilimi ve kültürlere bağlı olarak yeterince incelenmemiștir. Tarihi Türk anıt ve dokümanlarında cesaret ve kahramanlığın kaynakları incelendiğinde, ortaya çıkan sonuçları,bu kavramlardan sadece birisine ait olanlar ile ortak olanlar şeklinde ayırabiliriz.

Cesur yöneticilerin ayırt edici özellikleri, yüksek bir dehaya sahip olmak ve yetenekli olmaktır. Yöneticilerin, yönetim sorumluluklarını yerine getirmek, strateji oluşturmak, milletine hizmet edebilmek için farklı olmaları gerekmektedir. Bunu sağlamak için deha düzeyinde bir bilgi, muhakemeye sahip olmalıdırlar. Türk yazıtlarına göre yönetsel deha ve yeteneklere sahip olan yöneticiler gerekli cesur davranışları gösterebilmektedirler. Yöneticiler görev yaptıkları sürece ağır sorumluluklar yüklenmişlerdir. Sorumlulukların yerine getirilebilmesi için dönemin Orta Asya coğrafyasında gösterilecek ilk yönetsel özellik cesaret olmaktadır. Bilge Kağan bıraktığ yazıtlarda, çıplak milleti elbiseli, fakir milleti zengin, az milleti çok kıldığını, etrafındaki diğer milletleri kendine tabi kıldığını belirtmektedir. Metindeki başarıların sağlanabilmesi için milletin yüksek yetenek ve deha ile donanmış cesur bir yönetici lidere sahip olması gerekmektedir. Metinden kısa bir örnek vermek gerekirse Iltiriş-Kağan'ın cesur davranışları örnek gösterilebilir. "Iltiriş -Kağan bilici olduğu için, cesur olduğu için, Çine karşı on yedi defa savaşt1," (Ergin, 2011: 19).

Eski Türk anıtları, mezar taşları dönemin savaşçı, zafer kazanmış yöneticileri, liderlerine ait özellikleri günümüze aktarmaktadır. Metinlerde yer alan kişilerin ortak noktaları bir kahraman olmalarıdır. Örneğin yazıtlarda, Bumin Kağan etrafı hep düşmanla çevrilmiş ülkesini, asker sevk ederek dört taraftaki kavmi itaati altına almış, muti kılmış, başlılara baş eğdirmiş, dizlilere diz çöktürmüştür (Orkun, 1994: 15).
Dönemin coğrafyasında başarılı olabilmek için gerçek bir kahraman olmak gerekmektedir. Metinlerde geçen ayırt edici yönetici kahramanlık bileşenleri ise azimkârdık, zekâ, savaşçılık, otoriterlik, erlik ve erdem olarak sıralanabilir. Otoriterlik, azimkârdık ve savaşçılık devlet yönetimi yanında savaş meydanlarında zafer için olmazsa olmaz niteliklerdir. Diğer yazıtların yanında özellikle Çince yazılmış olan III. Uygur Yazıtında kahramanlığın bütünleyici bileşenleri sıklıkla geçmektedir. Yazıtta liderin öne çıkan ilk özelliği kahramanlıktır. Yazıtta kahramanlık, zekâ, savaşma, savaşçılık ve otorite ile ilişkilendirilmektedir (Orkun, 1938: 232-234). Metinden örnek vermek gerekirse, "Tun-Bağa Kağan kendi tacını (mevkiini) sağlamlaştırıyordu. O yüksek daha ve cesareti ile dâhili ve harici işleri vazih bir nizama bağlamıştır" (Orkun, 1938: 232-234).

Muharebe öncesi ve savaş meydanında gösterilmesi gereken davranışlara ilave olarak bir kahraman olarak sahip olunması gerekeli çok daha özel bir nitelik dikkati çekmektedir, erlik ve erdem. Yenisey nehri havalisinde bulunan yazıtlardan/mezar taşlarından olan Ulug-kem, Barlık ve Uybat yazıtlarında erlik ve erdem ifadeleri geçmektedir (Orkun, 1940: 553). Etik anlamlara sahip olan her iki kelime faziletli davranışları nitelendirmektedir. Savaşçılık, kahramanlık ve erdem yani fazilet, normalde pek yan yana gelmesi muhtemel özellikler olmasa da Türk yazıtlarında yer almaktadır. Metinlerde kahramanlık ile erdem ve buna yönelik davranışlar neredeyse eşdeğer sayılmaktadır. İncelenen kaynaklarda yöneticileri, ekiplerinde yer alan komutan, danışman vb. personelin kahramanlık konusunda ayırt edici bir bileşen bulunmamaktadır. Metinler içinden Uybat yazıtlarından örnek vermek gerekirse: "kahramanlığı için, erdemi için ittifak akdetti dört tarafla ittifak akdetti” (Orkun, 1940: 553) ifadesi belirtilebilir.

Metinleri incelediğimizde cesaretli yönetici ile kahraman yöneticilerin ortak noktası, yiğitlik ve alptir. Alp veya 
alpağu, alpagut; kahraman, cesur, yiğit, çetin, sert, müthiș, tek başına, düşmana saldıran, yakalanmayan asker, subay, bir subay rütbesi (Ergin, 1989: 52) kelimeleri ile eşanlamlı olarak kullanılmıştır. Alp, yiğit kişi varlığını milletine adayan bu uğurda her türlü çabayı gösteren kişidir. Benzer şekilde, eski ve orta Türkçede alp, Alpagu biçiminde tespit edilen kelimeler, eski Türk yazıtlarında 'zor, güç' gibi bir anlamın yanında unvan niteleyicisi olarak 'cesur, yiğit savaşçı' anlamında da kullanılmıştır (Aydın, 2011: 10). Alp kelimesi bir yaşam tarzının ifadesidir. Alp tipinin en büyük özelliği olan at üzerinde devamlı olarak hareket halinde bulunma, ilerlemedir (Şenocak, 2001: 169). Tanımlarda yer alan bütünleyici kelimelerin hem cesaret hem de kahramanlık ile aynı anlamları taşıdığı görülmektedir. Her iki özelliğin ortaya çıkıp gelişmesinin temel nedeni dönemin tarihsel ve coğrafi koşullarından kaynaklanmaktadır. Hareketli ve zorlu koşullarda başarılı olabilmek için stratejik özellikler taşımanın yanında dönemin koşullarında cesur ve kahraman birer yönetici olmak gerekmektedir. Kısaca yiğit, cesur olanlar kahraman olarak varlıklarını sürdürebilirler. Yazıt ve belgelerdeki kişiler bunu başarabilen kişilerdir.

Yazıtlarda dikkatimizi çeken bir özellik de topluluk içinde akılll, doğruyu görebilecek kişilere verilen önemdir (Şenocak, 2001: 169). Cesur yönetici, cesur maiyet ve kahraman yöneticilerin tamamında ortak olan nokta yönetici ve yardımcılarının akıllı ve bilge kişiler olmalarıdır. Göktürk ve Uygur dönemi metinlerinde bilge, kağandan başka öge "devletin danışmanı", beg "boyun, kabilenin başı", tamgaçı "damgacı, mühürdar", buyruk "kumandan", ayguçı "kağanın danışmanı, sözcüsü” gibi üst düzey devlet yetkililerini ve ata "baba", kişi "kişi”" gibi halk kitlesinin bireylerini de nitelemektedir (User, 2006: 221). Bilge kişi mevcut koşullarda kendisinin ve milletinin varlığını koruyup güçlendiren, onu yükseklere taşıyan liderdir.

Türk yazıtlarından Türk yönetim tarzına ilişkin çıkarımlar yapmak mümkündür. Eroğlu'na (2016) göre Türk yönetim düşüncesinin dayandığı ilkelerden "Kut ve Töre" (adalet) inancından sonra "bilgelik" gelmektedir. Eski Türklerde cesaretin ana bileşeninin olan bilgelik yönetici ve danışmanlarının sorumluluklarını yerine getirebilmek için sahip olması gereken tüm bilgileri kapsamaktadır. Yönetim kadrolarını dolduran kişilerin, öncelikle "akıllı", "bilge" ve "cesur" olmaları, yani yöneticilerin kaliteli olmaları, bir anlamda üstlendikleri görev ve sorumlulukları layıkıyla yerine getirmeleri anlamınagelmektedir (Eroğlu, 2016: 20). Bilgelik yalızca liderin değil yöneticilerinin de sahip olması gereken ortak niteliktir. Hanlarının bu bilge ve ileriyi gören danışmanının prototipi savaş dönemlerinde (Boratav, 2012: 90) etkin roller üstlenmişlerdir.

Cesaret, kahramanlık ve bilgelik Orta Asya'nın coğrafyasının, sosyal ve siyasi yapısının zorunlu bir koşuludur. Bölgenin ve coğrafyanın kurumsal yapısı anlaşılmadan yönetsel yap1 da anlaşılamaz. Devletin devamı törenin yaşaması ile mümkündür. Töreyi yaşatacaklar ilk kişiler yönetici ve ekibidir. Töre sınırlamaları ile şahıs hak ve topluluk menfaatlerinin çatışmasını önleyerek sosyal düzeni yürütebilmek için devlet başkanının, cesareti ve askerî bakımdan yeterliliği yanında tedbirli, ihtiyatlı ve ileri görüşlü, yâni eski deyimle "hakîm" yani“bilge" olması da gerekmektedir
(Kafesoğlu, 1997: 296). Başarılı bir liderin stratejik yönetici vasıflarına sahip olmalıdır. Geleceği değerlendirmek, planlamak ve uygulamak için de yeterli donanım ve liyakate sahip olunmalı yani bilen kişi olunmalıdır.

\section{Sonuç ve Değerlendirme}

Yöneticilerin sorumluluklarını yerine getirilebilmeleri için gerekli yeteneklere sahip olmaları gerekmektedir. Yönetici, lider pozisyonundaki kişilerin sahip olması gerekli yeteneklerden birisi de cesarettir. Cesaret bireysel ve toplumsal boyutta var olmanın, ilerlemenin vazgeçilmez bir unsurudur. $\mathrm{Bu}$ nedenledir ki, cesaret, tarihin ilk zamanlarından beri, düşünürlerin ilgisini çekmiş ve bu gizemli değerin anlaşılmasına yönelik bir gayret sarf edilmiştir.

Cesaret her ne kadar pek çok milletin, kültürün, toplumun önemsediği, ilk sıralara koyduğu bir değer olarak ortaya çıksa da, cesaret kavramının doğru anlaşılabilmesi için milli tarihsel, kültürel özelliklerin ve bu konudaki tespit ve uygulamaların keşfedilmesi gereklidir.

Günümüze kadar yapılan çalışmalarda cesaret, Sokrates, Konfüçyüs ve Platon'un eserlerinde yer alan uygulama ve hususlara bağlı olarak ele alınmıştır. Cesaret konusu üzerine yeterince araştırma yapılmamış olmasının bir nedeni olarak, cesaretin milli açıdan yeterince ele alınmaması gösterilebilir. Bundan dolayıdır ki, bu yönde yapılan çalışmaların yabancı yazında arttı̆̆ı görülmektedir.

Yapılan bu çalışma ile cesaret ve kahramanlığın, toplumsal kültürümüz açısından nasıl bir yapı ve bileşenlerle özümsendiği, örneklendirildiği tespit edilmeye çalışılmıştır.

$\mathrm{Bu}$ kapsamda, yönetsel cesaret ve kahramanlığın bileşenlerinin; yüksek deha sahibi olmak, maharetli olmak, bilgili olmak, azimli olmak, hakiki bir savaşçı olmak ve erdemli olmakla ilişkilendirildiği tespit edilmiştir.

Yapılan incelemede, Türk yazıtları, mezar taşları ve yazmalarda cesaretin yöneten/lider ve yönetim ekibinde yer alanlar ile yönetici/liderlerin cesaretle neredeyse eşdeğer kabul edilen kahramanlığının ortak noktası bilgelik ve akıldır. Elde edilen bulgular cesaretin ve kahramanlığın yönetsel boyutta ele alındığında,yöneticilerin cesaretle hareket edip birer kahraman olabilmeleri için yüksek bilinç, şuur seviyesine sahip yetenekli, bilge ve akıllı kişiler olmaları gerektiği belirtilmektedir.

Toplumda lider ve yönetici durumunda olan kişilerin, yönetmek ve etkilemek istedikleri kişilerin duygu ve düşüncelerine nüfus edebilmeleri, onlarda heyecan ve coşku oluşturabilmeleri, adanmaya varan bir sahiplenme ve gayret yaratabilmeleri, ancak toplumun temel esinlendirici değerlerine inebilen bir yaklaşımla mümkün olabilecektir. Diğer yandan, günümüz teknolojisinin etkisiyle hayli gelişmiş olan haberleşme vasıtaları, iletişim araçları, sosyal medya vb. hususlar dikkate alındığında, lider ve yönetici durumundaki kişilerin tutum, davranış, söylev ve özellikle de kararları, onların maiyetleri, takipçileri, paydaşları vb. tarafından kolaylıkla takip edilmekte ve bunun neticesinde yorumlanmakta ve de 
etkilenilmektedir. Dolayısıyla, günümüzün her alanda giderek artan uluslararası rekabet ortamında, ülkemizin en ön sıralara geçebilmesinde, lider ve yöneticilerimizin, milli dokumuza uygun bir liderlik yaklaşım, tutum ve davranış içerisinde olmaları çok önemlidir. Yapılan bu çalışma kapsamında ele alınan cesaretin daha derinden araştırılarak tekrar keşfedilmesi, doğru anlaşılması ve milli kültür ve dokumuza uygun olarak gerçek anlamda temel liderlik özelliği haline getirilebilmesi kaçınılmazdır. Lider ve yöneticilere verilen eğitimlerde, üniversitelerde verilen derslerde, liderlik ve yöneticilik üzerine yapılan araştırma ve yazılan tezlerde "cesaret" konusunun dâhil edilerek, içselleştirilesinin önemli bir fayda yaratabileceği değerlendirilmektedir.

Bundan sonra konu ile ilgili yapılacak çalışmalarda, kendi milli tarih ve kültürümüz ile uyumlu olan ve dolayısıyla da en etkin olarak kullanabileceğimiz cesaret model ve yaklaşımlarının geliştirilmesine ihtiyaç olduğu değerlendirilmektedir. Benzer çalışmaların farklı ve daha kapsamlı milli tarihsel yazıt ve kaynaklardan yapılarak, cesaretin adeta milli boyutta tekrar keşfedilmesine ihtiyaç olduğu değerlendirilmektedir.

Bununla birlikte cesaretin, liderlik ve yöneticilik konusunda nicel araştırma desenlerinin kullanıldığ araştırmalarda da bir değişken olarak ele alınmasının uygun olacağı düşünülmektedir.

\section{Kaynakça}

Allison, S.T.,\&Goethals, G.R.(2016). Hero Worship: The Elevation of the Human Spirit. Journal of Theory Social Behavior, 46 (2), 187-210.

Aydemir M. \&Mert,I. S. (2018). A Critical Review of Social Sciences Theory and Practice, A Study on the Investigation of the Historical Origins of Courage in Futuwwa and Akhi Institution. Frontpage Publications Limited, Editör: Yenihan Bora, Sarripek Doga Basar, Cerev Gökçe, 1,543-537.

Aydın, E. (2011).Yenisey Yazıtlarında Geçen Unvanlar ve Unvan Niteleyicileri, Belleten, 2011- 2, 5-26.

Bademci, A.(2014). Eski Türk Yazıtları'nda Tarih ve Sosyal Tarih Üzerine Bir Deneme, Uluslararast Türklerde Tarih Bilinci ve Tarih Yazıcılı̆̆ Sempozyити, 29-42.

Boratav N. P.(2012).Türk Mitolojisi.Ankara: BilgeSu Yayınc1lik.

Cavanagh, G. F., \& Moberg, D. J. (1999). The Virtue of Courage Within the Organization. In M. L. Pava \& P. Primeaux (Eds.), Research in Ethical Issues in Organizations,(1-25). Stamford, CT: JAI Press, Inc.

Clancy, T. R. (2003). Courage and Today's Nurse Leader. Nursing Administration Quarterly, 27, 128-132.

Comer, D., Sekerka, R. \& Leslie E. (2018).Keep Calm and Carry on (Ethically): Durable Moral Courage in the Workplace. Human Resource Management Review, 28, 116-130.
Enginün, İ.(2010). Orhun Yazıtları: Besleyici Güç, III. Uluslararası Türkiyat Araştırmalart Sempozyumu, Orhon Yazıtlarının Bulunuşundan 120 Yll Sonra Türklük Bilimi ve 21. Yüzyll.,341-347.

Ergin, M.(1989).Orhun Abideleri.İstanbul: Boğaziçi Yayınlar1.

Ergin, M.(2011).Orhun Abideleri.İstanbul: Boğaziçi Yayınlar1.

Eroğlu, F.(2016). Göktürklerde Yönetim Düşüncesi.Yeni Fikir, 7(16), 16-28.

Evans, P. D.\& White, D. G. (1981). Towards an Empirical Definition of Courage. Behavioral Research and Therapy, 19, 419-424.

Franco, Z.E.,Blau, K.\&Zimbardo, P.G. (2011). Heroism: a Conceptual Analysis and Differentiation Between Heroic Action and Altruism. Review of General Psychology, 15(2), 99-113.

Gould, N. H. (2005). Courage: Its Nature and Development. Journal of Humanistic Counseling, Education and Development, 33, 102-116.

Gömeç S. (2000). İslam Öncesi Türk Tarihinin Kaynakları Üzerine.Tarih Araştırmaları Dergisi, 31(20), 51-92.

Harbour, M.\&Kisfalvi, V. (2014). In the Eye of the Beholder: An Exploration of Managerial Courage. Journal of Business Ethics, 119(4), 493-515.

Hobbs, A. (2000). Plato and the Hero: Courage, Manliness and the Impersonal Good. Cambridge, UK: Cambridge University Press.

Howard, Matt C. \&Cogswell Joshua E. (2018).The Left Side of Courage: Three Exploratory Studies on the Antecedents of Social Courage, The Journal of Positive Psychology, 13(1), 1-19.

Kafesoğlu, İ.(1997).Türk Millı̂ Kültürü, İstanbul: Ötüken Neşriyat.

Jiang, X. (2012). Confucius's View of Courage, Journal of Chinese Philosophy, 39(1), 44-59.

Kilmann, R. H., O’Hara, L. A., \& Strauss, J. P. (2005). Developing and Validating a Quantitative Measure of Organizational Courage. Journal Business of Phychology, 25, 15-23.

Klein, M., \& Napier, R. (2003). The Courage to Act: 5 Factors of Courage to Transform Business. Palo Alto, CA: Davies- Black Publishing.

Kohen, A. (2014). Heroism and Subjectivity. Retrieved from. http://kohenari.net/post/99653156590/.(21.12.2018)

Lopez, S. J. (2007). Profiling Courage: Introduction to the Special Issue on Courage. The Journal of Positive Psychology, 2(2), 79.

Lopez, S. J.,Rasmussen, H. N., Skorupski, W. P., Koetting, K., Petersen, S. E., \&Yang, Y. T. (2010). Folk Conceptualizations of Courage. In C. L. S. Pury, \& S. J. Lopez (Eds.), The Psychologyof Courage: Modern 
Research on an Ancient Virtue (pp.23-45).

Washington, D. C. : American Psychological Association.

May, D. R.,Luth, M. T., \&Schwoerer, C. E. (2014). The Influence of Business Ethics Education on Moral Efficacy, Moral Meaningfulness, and Moral Courage: A quasiexperimental Study. Journal of Business Ethics, 124(1), 67-80.

Mert, İ. S. (2007). Cesaret Yönetimi, İstanbul: Hayat Yayınları.

Mert, İ. S. (2010). Terör Yönetimi Kuramı ve Cesaret: Kavramsal Bir Tartışma. Güvenlik Stratejileri Dergisi, 6(12), 57-80.

Mert, İ. S. (2018). En Üstün Ruhsal Özelliklerimizden Biri: Cesaret. Gönül Kültür ve Medeniyet Dergisi, 84, 12-19.

Orkun, H. N.(1938).Eski Türk Yazıtları II.İstanbul: Devlet Basimevi.

Orkun, H. N.(1940).Eski Türk Yazıtlarl III.İstanbul: AlaeddınKıral Basımevi.

Orkun, H. N. (1994).Eski Türk Yazıtları.Ankara: Yükseköğretim Kurulu Matbaası.

Öztürk, A.(1996).Ötüken Türk Kitabeleri.İstanbul: Ötüken Yayınları.

Peterson, C., \& Seligman, M. E. P. (2004). Character Strengths and Virtues: A Handbook and Classification. Washington, D. C.: American Psychological Association.

Platon, (2001).Lysis Yahut Dostluk, Lakhes Yahut Cesaret. (Çev.Sabahattin Eyüboğlu, N. Şazi Kösemihal). İstanbul: Sosyal Yayınlar.

Putman, D. (1997). Psychological Courage. Philosophy, Psychiatry and Psychology, 4(1), 1-11.

Rachman, S. (1984). Fear and Courage, Behavior Therapy, 15(1), 109-120.

Sekerka, L. E.,Bagozzi, R. P., \& Charnigo, R. (2009). Facing Ethical Challenges in the Workplace:
Conceptualizing and Measuring Professional Moral Courage, Journal of Business Ethics, 89(4), 565-579.

Shelp, E. E. (1984). Courage: A Neglected Virtue in the Patient-Physician Relationship. Social Science and Medicine, 18(4), 351-360.

Simola, S. (2015). Understanding Moral Courage Through a Feminist and Developmental Ethic of Care. Journal of Business Ethics, 130(1), 29-44.

Sullivan, M.P., \& Venter, A. (2010). Defining Heroes Through Deductive and Inductive Investigations. $J$. Soc. Psychol, 150(5), 471-484.

Şenocak, E.(2001). Göktürk Yazıtlarında Türk Halk Edebiyatı Unsurları. Firat Üniversitesi Sosyal Bilimler Dergisi, 11(2), 165-176.

Snyder, C. R., Lopez, S. J., \&Pedrotti, J. T. (2010). Positive Psychology: The Scientific and Practical Explorations of Human Strengths. CA: Thousand Oaks Sage.

User, H. Ş.(2006). Eski Türkçede Bazı Unvanların Yapısı Üzerine, Bilig, Güz (39), 219-238.

Walton, D. N. (1986). Courage:A Philosophical Investigation. Los Angeles: University of California Press.

Woodard, C. R. (2004). Hardiness and the Concept of Courage. Consulting Psychology Journal: Practice and Research, 56, 173-185.

Yılmaz, S.(2018). Eski Türk Runik Harfli Metinlerdeki Askerî ve Siyasî Terimler ile Unvan Niteleyicilerin Özbek Türkçesindeki İzleri. Uluslararası Beşeri Bilimler ve Ĕgitim Dergisi, 4 (7), 260-296.

Zimbardo, P.(2007). The Lucifer Effect. How Good People Turn Evil. New York, NY, US: Blackwell Publishing Ltd.

Zushe, Y. (2018).The Cultural Discovery and Practical Implications of Chinese Values. Social Sciences in China, 39(3),

69-84. 